\title{
The effect of storage on the microbiological quality of formulated breadfruit beverage (Treculia africana)
}

\author{
Nwakalor, Chizoba N. \\ Department of Food Science \& Technology, Federal Polytechnic, Oko, Anambra State
}

Email address:
chizobanwakalor@ymail.com

To cite this article:

Nwakalor, Chizoba N.. The Effect of Storage on the Microbiological Quality of Formulated Breadfruit Beverage (Treculia africana). Journal of Food and Nutrition Sciences. Vol. 2, No. 5, 2014, pp. 215-219. doi: 10.11648/j.jfns.20140205.12

\begin{abstract}
Vegetable milk beverage was produced from African breadfruit (Treculia africana) seeds using different treatments. A commercial soymilk (vitamilk) and home prepared soymilk served as controls. The storage stability of the beverages was monitored at ambient conditions $\left(25 \pm 2^{\circ} \mathrm{C}\right.$ and $\left.\mathrm{RH} 87 \%\right)$ for three months using microbiological quality as stability index. All the beverages were subjected to microbiological analysis using standard methods. Shelf life studies showed a minimal presence of TVC that ranged from $1.2 \times 10^{2}$ to $2.50 \times 10^{2}$ and the coliform count ranged from $2.58 \times 10^{2}$ to $3.00 \times 10^{2} \mathrm{cfu} / \mathrm{ml}$ after three months storage. This suggested that the formulated beverages might be stored for three months at ambient conditions without spoilage or deterioration. It is recommended that the use of preservatives in order to increase shelf stability should be adopted.
\end{abstract}

Keywords: Beverage, African Breadfruit, Storage, Microbiological Quality

\section{Introduction}

Beverages are diverse groups of commodities which are essential drinks. Some beverages like dairy milk are consumed for their food value while others are consumed for their thirst-quenching properties, stimulating effects, or simply because consumption is pleasurable (Potter and Hotchkiss, 1995). Beverages could be distinguished from other foods by two principal characteristics. First, they are liquids and consumed in the liquid state. Secondly, they are either consumed for their stimulating effects or simply because consumption is pleasurable. Some people especially children consume beverages because of the energy contributed by beverages (Fisher et al.2001). The essential component of any beverage is the water that it contains; other components such as stimulants, colouring and flavouring ingredients may perform some useful functions but they are not essential to the proper physiological functioning of the body (Potter and Hotchkiss, 1995). Majority of people prefer to take their water in the form of beverages -usually as non-alcoholic beverage such as soft drink. Such beverages are more likely to be appreciated for their flavour or stimulating action rather than for their nutritional value, while some beverages are drunk for their nutritional value.
Beverages are generally classified into alcoholic and non-alcoholic beverages. Alcoholic beverages are valued on account of their flavour and stimulating effect and hardly at all as a source of energy. Non-alcoholic beverages are the class of beverages whose production does not involve fermentation to produce alcohol and they can be carbonated or non-carbonated beverages.

Carbonated beverages are those drinks that are impregnated with $\mathrm{CO}_{2}$ gas. They include brand names like Coca cola, Fanta, Sprite and Tonic water. The general ingredients used for the production of carbonated beverage such as soft drinks include water, $\mathrm{CO}_{2}$, syrup, sweetener, acidulants, stabilizers, clouding agents and foaming agents (Woodroof and Philips, 1981). Carbonation adds sparkle, vim and zest to this class of beverages. Non- carbonated, non- alcoholic beverages may go under a variety of names like fruit drinks, breakfast drinks, nectar, treats and juices and may include such items as tea, coffee and cocoa based beverages.

Apart from the classification above, some beverages can be categorized on the basis of their sources either from animals or plants. Beverages from animals are natural and can be named after the animal source for instance cow milk, goat milk and human milk. Unlike the animal milk, vegetable milk (imitation milk) can be obtained from many plant products like legumes and oilseeds such as soybeans. 
In countries where there is scarcity of milk supply and ever increasing gap between the population and demand, efforts have been made over the years to develop alternative milk-like products from vegetable or plant sources. According to Obizoba and Anyika (1994), vegetable milk has been recommended for consumers including babies, who do not take human milk either for religious or medical reasons like in milk allergies and galactosemia. Nutritionally also, there is a gradual shift from over dependence on animal fat and protein because of the attendant health implications, to proteins of plant origin which have less record of incidences of cardiovascular and other degenerative diseases (Gaman and Sherrington, 2001). Generally, in West Africa, there is need for readily available, high quality alternative protein and energy sources that are inexpensive. This would reduce protein-calorie malnutrition and also help to alleviate poverty in region. The development of imitation milk (vegetable milk) from legume is an alternative or possible way of producing an acceptable nutritious food based on vegetables.

Imitation milk is a term that has been used to describe products that resemble milk but contains neither milk fat nor other important dairy product (Potter and Hotchkiss, 1995). Similarity of the functional properties, nutritive value and sensory characteristics of these milk analogues allow them to be used as substitutes for animal milks (Enwere, 1998). Imitation milks are produced from vegetable or plant produce hence the name vegetable milk.

Vegetable milks have found use in extending or replacing animal milk. The milk could be used for babies, who do not take human milk either for ethical reasons of for medical reasons as in milk allergies and galactosemia (Obizoba and Anyika, 1994). According to Akinyele and Abudu (1990) vegetable milk has been recommended for those who have suffered from or are prone to degenerative heart diseases that need milk with unsaturated fat as a replacement for creamy milk. It has equally offered a practical approach to improving diet of those in need of protein.

Vegetable milks have been developed from oil seeds and legumes such as soybean, cowpea, bambara groundnut, melon seeds and cotton seed (Akinyele and Abudu, 1990; Abu-Foul et al., 1992). These milks are basically prepared by grinding soaked beans into a puree, processing to extract the milk and boiling, but the formulation may be different. The most popular imitation milk is soymilk which has been prepared for hundreds of years in the orient by soaking the beans in water for several hours, draining and grinding with fresh water (Osho, 1989).

Banigo et al.,(1986) prepared soymilk from soybeans using modified process which involved cleaning, soaking, blanching, grinding, filtration, dilution and product formulation. Yazici et al., (1997) prepared a heat stable calcium fortified soymilk by adding full soy flour to heated water, blended, formulated, homogenized, sieved, pasteurized and cooled in a refrigerator. Karibo (1989) developed egusi milk by a modified Illinois process involving preliminary cleaning, soaking, blanching, "hot" grinding, filtration, pasteurization, formulation and homogenization. Extraction of milk from four different cultivars of cowpea was investigated by Akinyele and Abudu (1990).

Obizoba and Egbuna (1992) developed vegetable milk from Bambara groundnut employing both germination and fermentation principles. This was aimed at increasing the quality and availability of nutrient present in milk. Odo (2001) also developed groundnut milk by employing both germination and fermentation principles. This was aimed at increasing both the quality and availability of nutrients present in the milk. Nnam (1997) developed vegetable milk from African yam bean and maize blend. The process which involved the use of fermented and unfermented African yam bean flour and maize blends was aimed at increasing the nutritive value of the milk.

Some of the problems associated with vegetable milk includes the following:

- Beany flavour: imitation milks generally have a characteristic unacceptable flavour which results from the lipoxygenase oxidation of linoleic and linolenic acids, esters and triacylglycerol producing ketones and aldehydes (How and Morr, 1982).

- Instability: phase separation is another major problem associated with imitation milk. Storage instability of soymilk concentration has constrained the widespread use of the beverage, particularly in tropical countries (Nsofor et al. 1997).

African breadfruit (Treculia africana) is a leguminous crop with fruit heads. It contributes immensely to the diet of the people of Nigeria. It is widely consumed in southern Nigeria, especially among the traditional communities in Igbo land. It is an average sized tropical tree with flowers crowded in compact heads (Ejiofor et al.1988). The African breadfruit tree (Treculia africana Decne Var africana) is a native of many parts of Western and tropical Africa. It can be found in Sudan, Mozambique and Angola. It is always a common feature of evergreen and deciduous forest, found often by streams and may sometimes by plant. In Nigeria, it is very common in western and eastern States. This common forest tree is given many names by various localities where it is found. For instance, the Igbos call it "ukwa," the Yorubas, "afon," the Binis, "Ize," the Hausas, "Barafuta," "Kwakwa," in Higidi while the Efiks and Ibibios call it "ediang."

The most interesting thing about African bread fruit is the different ways it is eaten. A large number of traditional food preparation are made from various species of legumes (Wijeratne and Nelson, 1987). The differences in the form are related in part to food habits(i.e. ethnic background, customs and traditions) (Ihekoronye and Ngoddy, 1985), but the process steps in the various localities generally include boiling in water with ingredients like salt, pepper, crayfish and dry fish. This is the commonest method of preparing Treculia africana seeds in eastern part of Nigeria and the product is a thick porridge. Depending on one's choice, oil could be added. In some cases, shortly before 
the consistency thickens a substantial amount of the liquid constituent is run off into a dish, which can be drunk as a beverage. In certain towns in Anambra (eg Awka) and Enugu (Oji River), the porridge from whole dehulled breadfruit seeds could be cooked with seeds of maize or guinea corn.

The small brown seeds have a groundnut flavour when roasted; they are sold in this form in the open market by the Igbos in Nigeria. The seeds, the bran, (husk) and pulp are highly nutritious. Ejiofor et al., (1988) recorded high nutrient values for the bran and the pulp of African breadfruit which make them useful locally as livestock feed. Okafor (1990) discussed the dietary importance of this fruit in Nigeria and classified it as an important source of human and animal food. The contribution of the seeds of Treculia africana to native diet goes far beyound the ordinary boiling and eating. They are now processed and used for making breadfruit flour which serves various purposes in local communities. It is used for soup thickening and for making breadfruit cakes, snacks and cookies. If well processed, the seeds yield edible oils, which are used for food.

Some of the constraints to the utilization of Treculia africana seeds includes the following:

Legumes (eg. Treculia africana) are known to contain anti-nutritional components such as trypsin inhibitors, urease, goitrogens etc and this prevents efficient utilization of the legume proteins (Ihekoronye and Ngoddy, 1985).

The cooking time of most legumes contribute to the constraint of their utilization. Certain varieties of Treculia africana (Var mollis and Var. inversa) actually take considerable period of time before they are properly cooked for eating. A cooking time of an hour and thirty minutes have been reported. Consumption of Treculia africana seeds when boiled results in flatulence is accompanied or followed by diarrhea in some individuals. No observable effect is noted on consumption of the roasted seeds of Treculia africana seeds. Also the hard-to-cook phenomenon experienced with other legumes especially after long storage periods is another major constraint to the utilization of legumes. As the storage period of legume increases, there is a tendency for the grains to develop hard-to-cook phenomenon. Thus it takes a longer period to cook the legumes with the current high cost of fuel (energy) and this may constitute a great constraint to the utilization of legumes for food.

\section{Materials and Methods}

The breadfruit seeds were procured from Nsukka main market. The breadfruit seeds were cleaned to remove foreign matter. Different processing methods (treatments) were used for the development of breadfruit milk beverage. Different portions of $50 \mathrm{~g}$ each of dehulled breadfruit seeds were washed and boiled in different volumes of water $1: 1$, $1: 2$, (seed to water ratio $\mathrm{w} / \mathrm{v}$ ) for $1 \mathrm{hr} 15 \mathrm{mins}$ ( $75 \mathrm{mins}$ ).
After boiling, the liquid was decanted and used to formulate the beverage which contained $0.2 \%$ sugar( based on the volume of liquid decanted), $0.2 \%$ salt, $0.1 \%$ of vanilla flavour, pasteurized at $60^{\circ} \mathrm{C}$ for $30 \mathrm{mins}$,packaged in a screw capped plastic bottles (cans) and stored at ambient condition $\left(29 \pm 2^{0} \mathrm{C}\right.$, RH $87 \%$ ) for 3months. Samples were withdrawn periodically (fortnightly) and subjected to microbiological test. Homemade soymilk and vitamilk were used as control. The total viable count, mould count and coliform count were determined forthnightly for 3 months and the method of Harrigan and McCance (1976) was used. Serial dilutions were first carried out. Samples were plated in triplicates and incubated for one week for mould growth. Enumeration of the discrete colonies was carried out using a Digital electronic colony counter (Gallenkamp colony counter, C NW 330-010x).

\section{- Total Viable Count}

The total viable count of the sample was carried out by pour plate method using nutrient agar as described by Harrigan and McCance (1976). Two milliliter of each beverage sample in a sterilized test tube was mixed with $9 \mathrm{ml}$ of Ringer's solution. Further dilution of this was made to obtain 10-1, 10-2, 10-3 and 10-4 concentrations. Thereafter $0.1 \mathrm{ml}$ dilution was transferred from each dilution into corresponding plate and $15 \mathrm{ml}$ of sterile nutrient agar medium poured and mixed thoroughly by rocking the plates. The plates were incubated at $370 \mathrm{C}$ for $48 \mathrm{hr}$ after which colonies formed were counted and expressed as colony forming units per gramme $(\mathrm{cfu} / \mathrm{g})$.

\section{- Mould Count}

The mould count for the beverage was done according to the method of Harrigan and McCance (1976) using potato Dextrose Agar (PDA) as the medium. Ringers solution was prepared by dissolving a tablet of $1 / 4$ strength Ringer's tablet in $500 \mathrm{ml}$ of distilled water and autoclaved for $15 \mathrm{~min}$. Two milliliters of beverage samples was put into serial dilution bottles which had been previously autoclaved and shaken for about 2 minutes. Serial dilution of $10-1$ to $10-3$ was done and the first and second (10-1 and 10-2) were used for mould count determination. One milliliter of the appropriate diluents was pipetted into the sterilized petri dishes. Melted potato dextrose agar was used for plating and left in the incubator to allow growth of mould. The mould count was expressed as colony forming units per milliliter (cfu/ml) of beverage sample. Dishes having less than 30 colonies or more than 300 colonies were discarded.

\section{- Coliform}

Analysis for coliform in the beverage was done according to the method of Harrigan and McCance (1976) using the MacConkey's broth. The use of MacConkey's broth with incubation for $48 \mathrm{hr}$ at $370 \mathrm{C}$. presumptive positive results ( acid and gas produced) was confirmed by streaking across MacConkey agar plates. After incubation, the number of colonies were counted. 


\section{Results and Discussion}

Table 1. Microbiological quality of breadfruit beverage, soymilk and vitamilk

\begin{tabular}{|c|c|c|c|c|c|c|c|c|c|c|c|c|c|c|}
\hline \multirow{3}{*}{ Samples } & \multicolumn{10}{|c|}{ Storage Period (days) } & \multicolumn{4}{|l|}{---} \\
\hline & $\overline{0}$ & & 15 & & 30 & & 45 & & 60 & & 75 & & 90 & \\
\hline & TVC & C Coliforı & mTV & CColiform & TVC & Coliform & TVC & Coliform & TVC & Coliform & TVC & Coliform & ITVC & Coliform \\
\hline $\mathrm{BWBA}_{\mathrm{Su}}$ & - & - & - & - & - & - & - & - & - & - & - & - & - & - \\
\hline $\mathrm{BWBB}_{\mathrm{SU}}$ & - & - & - & - & - & - & - & - & - & - & - & - & - & - \\
\hline $\mathrm{BNWA}_{\mathrm{SU}}$ & - & - & - & - & $1.20 \times 10^{2}$ & - & $1.40 \times 10^{2}$ & - & $1.50 \times 10^{2}$ & - & $1.60 \times 10^{2}$ & & $1.62 \times 10^{2}$ & - \\
\hline $\mathrm{BNWA}_{\mathrm{SU}}$ & - & - & - & - & - & - & - & - & - & - & - & - & - & - \\
\hline Soymilk & - & - & - & - & $1.95 \times 10^{2}$ & $2.58 \times 10^{2}$ & $2.00 \times 10^{2}$ & $2.68 \times 10^{2}$ & $2.00 \times 10^{2}$ & $2.75 \times 10^{2}$ & $2.00 \times 10^{2}$ & ${ }^{2} 2.98 \times 10^{2}$ & $2.00 \times 10^{2}$ & $3.00 \times 10^{2}$ \\
\hline Vitamilk & - & - & - & - & $2.23 \times 10^{2}$ & $2.88 \times 10^{2}$ & $2.48 \times 10^{2}$ & $2.70 \times 10^{2}$ & $2.50 \times 10^{2}$ & $2.89 \times 10^{2}$ & $2.50 \times 10^{2}$ & ${ }^{2} 2.89 \times 10^{2}$ & $2.54 \times 10^{2}$ & $3.00 \times 10^{2}$ \\
\hline
\end{tabular}

BWBA $_{\mathrm{SU}}$ - boiled and wet milled breadfruit beverage which sugar was added (1:1); BNWA $\mathrm{sU}$ - boiled with sodium bicarbonate and wet milled breadfruit beverage which sugar was added (1:1); vitamilk (control); soymilk (control);

BWBA $_{\mathrm{SU}}$-boiled and wet milled breadfruit beverage which sugar was added (1:2); BNWA $\mathrm{SU}_{\mathrm{SU}}$ - boiled with sodium bicarbonate and wet milled breadfruit beverage which sugar was added (1:2).

TVC- Total Viable Count

There were no presence of mould and coliform bacteria in the formulated beverage, soymilk and vitamilk from 0 to 15 days of storage. This could probably be attributed to the heat treatment (boiling and pasteurization) that were given to the beverage during the processing. Similar results were reported by Rustom et al.,(1995) in peanut beverages that were sterilized under two different UHT conditions. Heat is known to improve the availability of some nutrients, inactivate enzymes that speed up nutrient damage and destroy undesirable microorganisms and food contaminants as well as favourably change the physical attributes of food such as colour, texture and flavour (Lawal, 1986). After 30days to 90days of storage, samples $\mathrm{BNWA}_{\mathrm{SU}}$, soymilk and vitamilk showed a TVC range of $1.2 \times 10^{2}$ to $2.50 \times 10^{2}$ and the coliform range from $2.58 \times 10^{2}$ to $3.00 \times 10^{2} \mathrm{cfu} / \mathrm{ml}$. Also, there was no mould growth during the storage period.

\section{Conclusion}

The storage studies revealed that the beverage could keep well for 3(three) months at ambient temperature since the microbial analysis showed that the microbial load was low, but the most optimal storage was 30days of storage.

\section{References}

[1] Abu-Foul, N.S., Ayyat, M. and Moharram, Y.G.(1992). Milk, curd and yoghurt from glandless and deggosypolised glanded cottonseed protein. Food and Nutrition Bulletin, 14(2): 1-8.

[2] Adeparusi, E.O.(2001). Effect of processing on some minerals, anti-nutrients and nutritional composition of African yam bean. J. Agric. Environ, 3(1): 101-108.

[3] Akinyele, I.O. and Abudu, I.A. (1990). Acceptability and nutrient content of milk substitutes from four cowpea (Vigna unguiculata). J.Food Sci., 55(3): 701-702.

[4] Banigo, E.O.I., Ihimoyan, K.J. and Ossai, G.E.A. (1986). Development of soy beverage for Nigeria. Nig. Food J., 4: 53-64.
[5] Ejiofor, M.A.N., Obiajulu, O.R. and Okafor, J.C.(1988) "Diversifying utilities of African breadfruit as food and feed." Int. Tree Crops J., 5: 125-135.

[6] Fisher, J., Mitchell, D., Smicklass-Wright, I. and Birch,L.L.(2001). Material milk consumption predicts the tradeoff between milk and soft drinks in young girls diets. J.nutr., 131:246-250.

[7] Gaman, P.M. and Sherrington, K.B.(2001). The Science of Food. Butterworth Heinemann, Real, Educational and Professional Publ. Ltd. Oxford. Pp 1-15.

[8] Harrigan, W.F. and McCance, E.M. (1976). Laboratory Method in Food and Dairy Microbiology. Academic Press Inc., San Diego.

[9] How, J.S.L. and Morr, C.V. (1982). Removal of phenolic compounds from soyprotein extracts using activated carbon. J. Food sci., 47: 933-940.

[10] Ihekoronye , A.I. and Ngoddy, P.O.(1985). Integrated Food Science and Technology for the Tropics. Macmillian Publ. London.

[11] Karibo, B.P. (1989). Studies on egusi (Colocynthis citrullius L.) milk. B.Tech. Thesis. Federal University of Technology, Owerri.

[12] Lawal, R.O. (1986). Effect of roasting on the chemical composition of the seeds of T.africana. Food Chem.,22:305314.

[13] Nnam, N.M. (1997). Chemical and sensory evaluation of vegetable milks from African yam bean (Sphenostylis sternocarpa \{Hochst ex A Rich\} harms) and maize (Zay mays L.). Plant Food Hum., 51: 265-267.

[14] Nsofor, L.M., Bright, U. and Osuji, M.C. (1997). Storage stability and chemical properties of soymilk from sprouted soybeans. J. Food Sci. Technol., 34(6): 477-482.

[15] Obizoba, I.C. and Egbuna, H.I. (1992). Effect of germination and fermentation on the nutritional quality of bambara nut (Voandzei subterranean L. thourars), and its product (milk). Plant Foods Hum.Nut., 42: 13-23.

[16] Obizoba, I.C. and Anyika, J.U.(1994). Nutritive value of baobab milk (Gbudi)and mixtures of baobab (Adansoia digitala L.) hungary rice, acha (Digitaria exillis) flours. Plants Foods Hum.Nutr.,46:156-165. 
[17] Odo, F.O.(2001). Consumer acceptance of groundnut milk. A paper presented at the $25^{\text {th }}$ Annual Nigerian Institute of Food Science \& Technology (NIFST) Conferences, Nov.5-9, pp 135-137.

[18] Osho, S.M.(1989). Soybean for household use. In: Food Crop Production, Utilization and Nutrition, B.N. Mbah and D.O. Nnayelugo, (Ed.)Dotan Publ.Ltd., Ibadan, pp. 109-115.

[19] Potter, N.N. and Hotchkiss, J.H.(1995). Food Science. (5 $5^{\text {th }}$ edn.). Chapman and Hall, International Thomson Publ., New York, pp 437-441.

[20] Rustom, I.Y.S., LÓpez -Leiva, M.H. and Nair, B.M.(1995). Nutritional, sensory and physicochemical properties of peanut beverage sterilized under two different UHT conditions. Food Chem., Vol.56(1):45-53.
[21] Wijerane, W.B. and Nelson, A.I. (1987). Utilization of legumes as food: In Aciar proceedings, No. 18. Khoh Kaen, Thailand pp183-191.

[22] Woodroof, J.G. and Philips, G.F. (1981). Beverages: Carbonated, Non- Carbonated. AVI, Westport, CT.pp 343349.

[23] Yazici, F.V.B., Alvarez, V.B., Mangino, M.E. and Hansen (1997). Formulation and Processing of a Heat Stable Calcium Fortified Soymilk. J.Food Sci., 62(3): 535-538. 